\title{
Forthcoming Special Issues
}

I. Theatre and Madness - Theatre and Therapy

2. The Theatre through the looking-glass of the human sciences

Potential contributors are requested to send a brief résumé to:

Georges Baal, ıo, Impasse Pierre-Rouge, F 34000 Montpellier, France.

For further details, see TRI, Volume 9, Number 3, Autumn I984, pp. 266-8

\section{Numéros Spéciaux en préparation}

I. Théâtre et folie - Théâtre et thérapie

2. Le théâtre dans le miroir des sciences de l'homme

Les personnes intéressées sont priées d'adresser une note brève à:

Georges Baal, Io, Impasse Pierre-Rouge, F 34000 Montpellier, France.

Pour plus de détails voir TRI, Volume 9, Number 3, Autumn r984, pp. 266-8 


\section{READY NOW:}

FIRST ANNUAL ISSUE

\section{International Bibliography \\ of}

Theatre:

1982

Published by: The Theatre Research Data Center at Brooklyn College Sponsored by: The American Society for Theatre Research

: The International Association of Libraries and Museums of the Performing Arts

In cooperation with: The International Federation for Theatre Research

\section{ORDER NOW}

PUBLISHING CENTER, 625 BROADWAY, NEW YORK 10012

INSTITUTIONS \$65

INDIVIDUALS $\$ 50$ 


\section{The French Stage of Playhouse in the Seventeenth Century}

\section{by \\ T. E. LAWRENSON}

The second, revised and up-dated edition of The French Stage in the XVIIth Century, which was a landmark in its subject, is now in the press and will be available in early Spring 1986, from the AMS Press, New York.

Professor Tom Lawrenson, who was Secretary General of the International Federation for Theatre Research from 1973 until his death in 1982, completed the manuscript himself. It is now being offered as a memorial volume which includes an appreciation of the author, a bibliography of his published work, lists of productions which he directed and of roles which he played.

Subscriptions at the pre-publication price of $£ 24.00$ can still be accepted up to 31 December 1985.

(After publication the price will be $\$ 47.50$ ) Cheques should be made payable to the Lawrenson Memorial Fund $\mathrm{A} / \mathrm{C}$ and sent to Dr L. M. Newman, University of Lancaster Library, Lancaster LA1 4YH, Great Britain.

For America and Canada $\$ 30.00$, payable to AMS Press, should be sent to DrW. B. Long, AMS Press, 56 East 13th Street, New York, N.Y. 10003, USA. 


\section{The Oxford Shakespeare}

General Editor: Stanley Wells

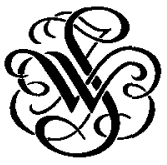

New and authoritative versions of Shakespeare's plays in which the early printings have been scrupulously re-examined and interpreted on freshly considered principles.

'Not simply a better text but a new conception of Shakespeare. This is a major achievement of twentieth-century scholarship.' Times Literary Bupplement

'. . . a practical working edition for actors.' Plays and Players Afready available: Julius Caesar, Henry V, The Taming of the Shrew, Titus Andronicus, Troilus and Cressida

New and fortficoming:

Hamlet

Edited by G. R. Hibbard

$£ 15$ hardback; $£ 4.25$ paperback

Henry IV, Part 1

Edited by David Bevington

$£ 15$ hardback; $€ 2.95$ paperback

The Tempest

Edited by Stephen Orgel

$£ 15$ hardback; $£ 2.95$ paperback

\section{Shakespeare}

\section{Germaine Greer}

'Shakespeare was and is a popular artist.' This is the theme of Germaine Greer's exciting new introduction to Shakespeare's work in the Past Masters series. She also explores why, several centuries after his death, Shakespeare is still central to English cultural life.

$£ 12.50$ hardback; $£ 3.95$ paperback

\section{Shakespeare}

\section{A Writer's Progress}

\section{Philip Edwards}

Professor Edwards stresses the continuity and inter-relationship of Shakespeare's work in a new study that encourages the reader to reach his or her own personal realization of Shakespeare's unique importance as a writer.

£12.50 hardback

\section{Oxford University Press}




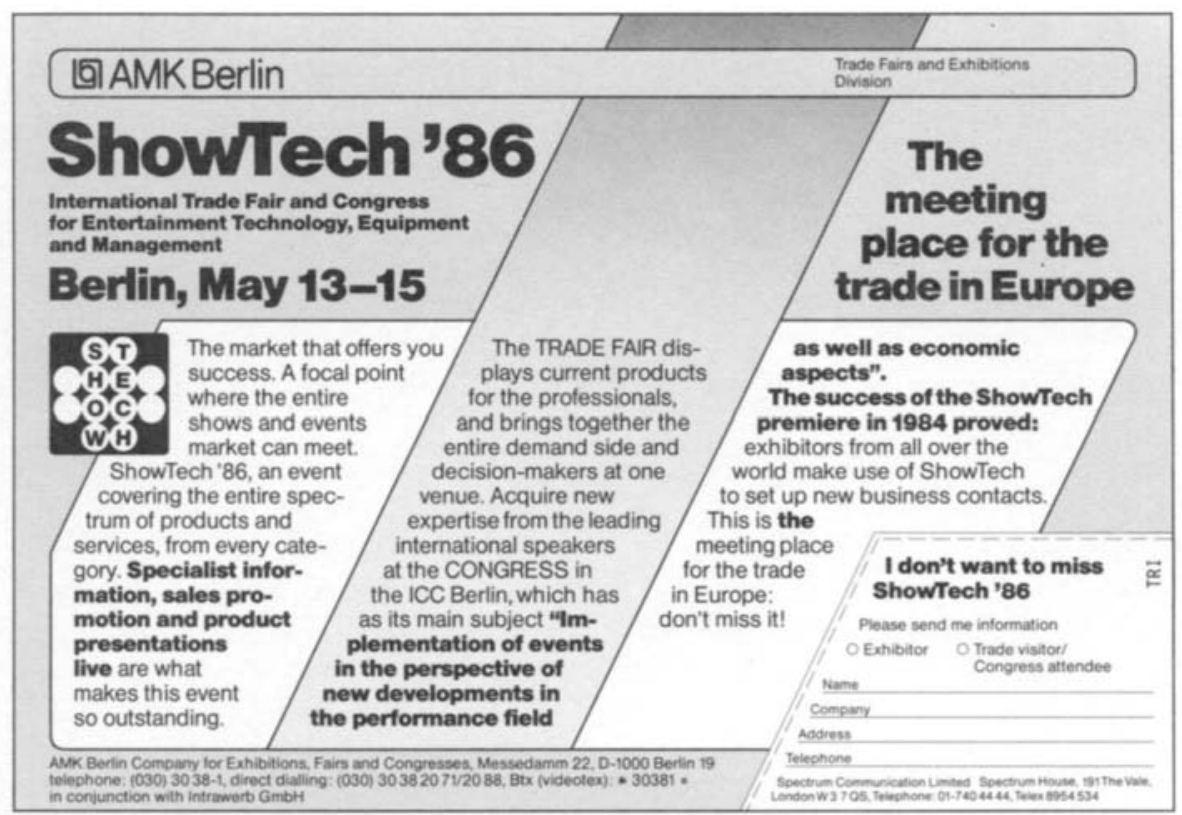

Our representetive: Spectrum Communication Limited Spectrum House, 191 The Vale, London W 37 QS, Telephone: 01-740 44 44, Telex: 8954534 


\title{
THE INTERNATIONAL FEDERATION FOR THEATRE RESEARCH LA FEDERATION INTERNATIONALE POUR LA RECHERCHE THEATRALE
}

\author{
Founded in 1957 with the following aims: \\ To promote in all countries international liaison between organizations and individuals \\ devoted to theatre research. \\ To organize international conferences and symposia. \\ To obtain facilities in libraries, museums, etc., for theatrical research workers of all \\ countries. \\ To submit to the authorities of all countries the desirability of creating courses, institutes \\ and chairs of theatre research.
}

The I.F.T.R. has the following sections:

THE VENICE INTERNATIONAL INSTITUTE FOR THEATRE RESEARCH.

THE UNIVERSITIES COMMISSION, specially charged with research within universities and the promotion of teaching of Theatre Studies throughout the world.

All members receive the journal Theatre Research International published by the Oxford University Press in association with the I.F.T.R.

FULL MEMBERS: ASSOCIATE MEMBERS: INDIVIDUAL MEMBERS:

MEMBERSHIP AND ANNUAL SUBSCRIPTIONS

Bodies whose sole function is theatre research. $180 \mathrm{Sw} . \mathrm{F}$. Bodies whose function is partly theatre research. $140 \mathrm{Sw} . F$ Individuals who wish to participate in the work of the I.F.T.R. and to support it. $65 \mathrm{Sw}$. F. reduced to $60 \mathrm{Sw}$. F. for individuals already belonging to a national institutional member.

Enquiries and application for membership should be addressed to Membership Secretariat, IFTR/FIRT 14 Woronzow Road, London NW8 6QE, Great Britain

\section{THEATRE RESEARCH / RECHERCHES THEATRALES}

The International Federation published the journal Theatre Research/Recherches Théatrales from 1959 to 1975 when it was succeeded by Theatre Research International. During these years many important articles of original research were published covering the whole field of theatre history from the earliest times, and particularly Shakespeare and the Elizabethan period, to more recent figures such as Strindberg, Craig and Beckett. There have been special issues on the themes of Opera, the Playwright as Director, and Reinhardt; a check-list of world theatre on records; and reports on International Conferences and Symposia of the I.F.T.R.

In all 14 volumes were published in $\mathbf{3 6}$ issues including a complete index. Most back issues are still available.

University and institutional libraries, and especially those who have subscribed to the new journal Theatre Research International, are recommended to take this opportunity of completing their holding of the earlier issues of this publication, while copies last.

Price: per issue 12 (\$3); per volume 44 (\$6) plus postage

A few complete runs of the 14 volumes (with two issues in facsimile) are available at 150 ( $\$ 75$ ). Postage extra.

Enquiries and Orders are invited to

THEATRE RESEARCH

14 WORONZOW ROAD, LONDON NW8 6QE 